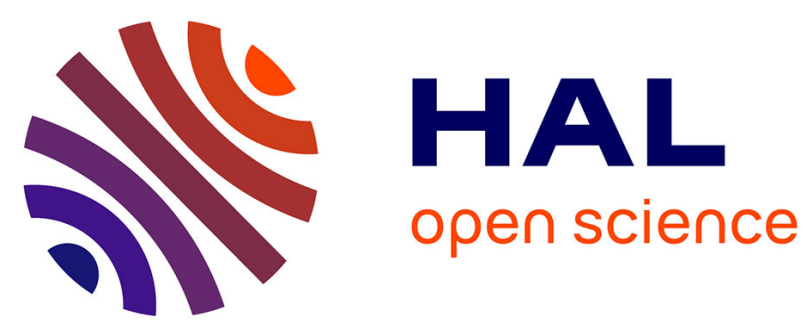

\title{
Effects of Sintering Temperature on Microstructural, Magnetic, and Impedance Spectroscopic Properties of Ni0.4Cd0.3Zn0.3Fe2O4 Ferrites
}

\author{
Nesrine Mechi, Abdulrahman Mallah, Sobhi Hcini, Mohamed Lamjed \\ Bouazizi, Michel Boudard, Abdessalem Dhahri
}

\section{To cite this version:}

Nesrine Mechi, Abdulrahman Mallah, Sobhi Hcini, Mohamed Lamjed Bouazizi, Michel Boudard, et al.. Effects of Sintering Temperature on Microstructural, Magnetic, and Impedance Spectroscopic Properties of Ni0.4Cd0.3Zn0.3Fe2O4 Ferrites. Journal of Superconductivity and Novel Magnetism, 2020, 33 (5), pp.1547-1557. 10.1007/s10948-019-05416-x . hal-03127736

\section{HAL Id: hal-03127736 \\ https://hal.univ-grenoble-alpes.fr/hal-03127736}

Submitted on 14 Oct 2021

HAL is a multi-disciplinary open access archive for the deposit and dissemination of scientific research documents, whether they are published or not. The documents may come from teaching and research institutions in France or abroad, or from public or private research centers.
L'archive ouverte pluridisciplinaire HAL, est destinée au dépôt et à la diffusion de documents scientifiques de niveau recherche, publiés ou non, émanant des établissements d'enseignement et de recherche français ou étrangers, des laboratoires publics ou privés. 


\title{
Effects of sintering temperature on microstructural, magnetic and
} impedance spectroscopic properties of $\mathrm{Ni}_{0.4} \mathrm{Cd}_{0.3} \mathrm{Zn}_{0.3} \mathrm{Fe}_{2} \mathrm{O}_{4}$ ferrites

\author{
Nesrine Mechi ${ }^{1}$, Abdulrahman Mallah ${ }^{2}$, Sobhi Hcini ${ }^{1}$, Mohamed Lamjed Bouazizi ${ }^{3, *}$, Michel \\ Boudard ${ }^{4}$, Abdessalem Dhahri ${ }^{5,6}$ \\ ${ }^{1}$ University of Kairouan, Faculty of Science and Technology of Sidi Bouzid, University Campus \\ Agricultural City, 9100 Sidi Bouzid, Tunisia. \\ ${ }^{2}$ Department of Chemistry, College of Science, Qassim University, Buraydah Almolaydah, Buraydah: \\ 51452 - P.O.Box: 6644: Saudi Arabia. \\ ${ }^{3}$ College of Engineering-Prince Sattam Bin Abdulaziz University, 655, Al Kharj 11942, Saudi Arabia. \\ ${ }^{4}$ LMGP, University of Grenoble Alpes, CNRS, 38000 Grenoble, France. \\ ${ }^{5}$ University of Monastir, Faculty of Sciences of Monastir, Department of Physics, Laboratory of \\ Physical Chemistry of Materials, 5019 Monastir, Tunisia. \\ ${ }^{6}$ Al-Qunfudah University College, Umm Al-Qura University, Saudi Arabia. \\ *Corresponding authors: E-mail address: medbouazizi75@gmail.com (M.L. Bouazizi). \\ hassini271185@gmail.com (S. Hcini)
}

\begin{abstract}
$\mathrm{Ni}_{0.4} \mathrm{Cd}_{0.3} \mathrm{Zn}_{0.3} \mathrm{Fe}_{2} \mathrm{O}_{4}$ ferrites have been prepared through the use of sol-gel method at $900{ }^{\circ} \mathrm{C}$ and $1100^{\circ} \mathrm{C}$. Rietveld refinements of XRD patterns indicate that the prepared samples crystallize in the cubic spinel structure. Lattice constant and grain size are found to increase with sintering temperature. Magnetic measurements show that the maximum magnetization $\left(M_{s}\right)$ rises; whereas both coercivity $\left(H_{c}\right)$ and remanence $\left(M_{r}\right)$ decrease when increasing the sintering temperature. Frequency and temperature dependence of electrical conductivity, electrical modulus and electrical impedance have been studied using impedance spectroscopy technique. As the sintering temperature increases, the conductivity of the samples increases. The variation of imaginary part of modulus $\left(M^{\prime \prime}\right)$ displays the presence of an electrical relaxation phenomenon and non-Debye nature. Nyquist representations have been analyzed using an electrical equivalent circuit. The obtained results reveal that the conduction mechanism of the samples is achieved basically of the grain boundary contribution.
\end{abstract}

Keywords Ferrites $\cdot$ Sol-gel method $\cdot$ Rietveld refinement $\cdot$ Hysteresis loops $\cdot$ Electrical properties 


\section{Introduction}

Spinel ferrites with structure $\mathrm{AFe}_{2} \mathrm{O}_{4}$ (where $\mathrm{A}$ is a transition metal) constitute an imperative class of magnetic materials that have attracted a great interest in various area. These compounds are used in gas sensors, microwaves devices, information storage systems, magnetic recording media, transducers and transformers, etc. [1]. Nonetheless, in order to broaden the performance of electronic applications of spinel ferrites, there is an important need to improve their electrical properties. The electrical properties of these materials can be optimized in taking into consideration numerous agents namely the preparation method, the type and amount of substitutionally elements, the sintering temperatures, the microstructure and chemical composition, the difference in ionic radii, and the cations distribution.

Among the spinel ferrites, the $\mathrm{Ni}-\mathrm{Zn}$ system has several interesting properties (low dielectric losses, high resistivity and Curie temperature, mechanical hardness, and chemical stability). These properties allow to this system to be used in several application areas such as low and high frequency applications $[2,3]$. Various compositions of $\mathrm{Ni}-\mathrm{Zn}$ system have been extensively examined [4-8]. As per the best of our knowledge, in order to ameliorate the technological applications for $\mathrm{Ni}-\mathrm{Zn}$ ferrites, researchers had tried to investigate and understand their anomalous properties (i.e. structural, electrical, magnetic etc.) with different substitutions. For example, A. Ghasemi reports the particle size dependence of magnetic properties of $\mathrm{Ni}_{0.6-\mathrm{x}} \mathrm{Cu}_{\mathrm{x}} \mathrm{Zn}_{0.4} \mathrm{Fe}_{2} \mathrm{O}_{4}$ spinel nanoparticles [9]. While B.R. Babu et al. have investigated the electrical and magnetic characterisations of $\mathrm{Ni}_{0.65-\mathrm{x}} \mathrm{Mg}_{\mathrm{x}} \mathrm{Zn}_{0.35} \mathrm{Fe}_{2} \mathrm{O}_{4}$ ferrites [10]. Also, M.M. Mallapur et al. have analyzed in their work the structural and electrical properties of $\mathrm{Ni}_{0.7-\mathrm{x}} \mathrm{Co}_{\mathrm{x}} \mathrm{Zn}_{0.3} \mathrm{Fe}_{2} \mathrm{O}_{4}$ spinel ferrites [11]. On the other hand, U. B. Gawas et al. have scrutinized the resistivity, the magnetic susceptibility and the dielectric properties of $\mathrm{Ni}_{0.6-\mathrm{x}} \mathrm{Mn}_{\mathrm{x}} \mathrm{Zn}_{0.4} \mathrm{Fe}_{2} \mathrm{O}_{4}$ samples [12]. For their part, M.R. Patil et al. have presented the structural, infrared, electrical and magnetic properties of $\mathrm{Cd}^{2+}$ doped Ni-Zn ferrites $[\mathbf{1 3}, \mathbf{1 4}]$. 
However, an adequate explanation of sintering temperature effects on the properties of $\mathrm{Ni}-\mathrm{Zn}$ ferrites is still lacking and offers further investigations. In this work, we have prepared using sol-gel method ferrites samples with $\mathrm{Ni}_{0.4} \mathrm{Cd}_{0.3} \mathrm{Zn}_{0.3} \mathrm{Fe}_{2} \mathrm{O}_{4}$ compositions, and we have successively investigated the effects of sintering temperature on their microstructural, magnetic and impedance spectroscopic properties. The results and discussion of the samples show some interesting properties and find many practical applications.

\section{Experimental}

\subsection{Synthesis process}

Sol-gel method was used to synthesize $\mathrm{Ni}_{0.4} \mathrm{Cd}_{0.3} \mathrm{Zn}_{0.3} \mathrm{Fe}_{2} \mathrm{O}_{4}$ ferrites as shown in Fig. 1. The stoichiometric amounts of nickel, cadmium, zinc and iron nitrates with high purity have been taken in the required molar weight ratio to meet the molecular formula of $\mathrm{Ni}_{0.4} \mathrm{Cd}_{0.3} \mathrm{Zn}_{0.3} \mathrm{Fe}_{2} \mathrm{O}_{4}$ samples. These nitrates were firstly dissolved in distilled water, and the solution was subjected to thermal stirring at $80{ }^{\circ} \mathrm{C}$. After complete dissolution of nitrates, controlled quantities of citric acid (which is used as complexation agent for the different metal cations) were added. The molar ratio of nitrates to citric acid was set at 1:1. Thereafter, we have carefully added amounts of ammonia in order to adjust the $\mathrm{pH}$ of the solution to about 7 . Stoichiometric amounts of ethylene glycol (which is used as a polymerization agent) were then added to the solution. After a certain time (about $4 \mathrm{~h}$ ), a viscous liquid (gel) is formed. The obtained gel was dried at $200{ }^{\circ} \mathrm{C}$ (for $6 \mathrm{~h}$ ) in an oven to obtain a dry foamy which was ground in a mortar, followed by drying at $500{ }^{\circ} \mathrm{C}$ for $12 \mathrm{~h}$ in air to eliminate the residual organic material. The obtained powder was pressed into pellets with diameter of $10 \mathrm{~mm}$ and thickness of about $2 \mathrm{~mm}$ and then sintered at $700{ }^{\circ} \mathrm{C}$ for $12 \mathrm{~h}$. Finally, the powder was ground and pressed again, and divided into two portions, which were sintered separately for $24 \mathrm{~h}$ at $900{ }^{\circ} \mathrm{C}$ and $1100^{\circ} \mathrm{C}$, respectively. 


\subsection{Characterizations}

The morphology of samples was examined in pellets form using SEM (Scanning Electron Microscope, Philips XL 30) equipped with an electron gun, with $20 \mathrm{kV}$ accelerating voltage. XRD patterns have been registered using "Panalytical X'Pert Pro System" two-circle automatic diffractometer operating at copper wavelength $(\lambda=1.5406 \AA)$ with a filter of Nickel to eliminate the $K_{\beta}$ ray. The measurement was made in Bragg Brentano geometry in a divergent beam, with $0.017^{\circ}$ step and 18 s counting time per step in an angular range of $10 \leq$ $2 \theta \leq 80^{\circ}$. Rietveld method using FullProf software was used for structural parameters determination [15]. To record the magnetization measurements, a Vibrating Sample Magnetometer (VSM, Quantum Design PPMS) was used. By this instrumentation, the room temperature magnetic field variation of magnetization, $M(H)$, was registered. Electrical characterizations were obtained using N4L-NumetriQ (model PSM1735) analyzer at different temperatures over the frequency range of $10^{2} \mathrm{~Hz}-10^{7} \mathrm{~Hz}$.

\section{Results and discussions}

The SEM micrographs and particle size distributions for $\mathrm{Ni}_{0.4} \mathrm{Cd}_{0.3} \mathrm{Zn}_{0.3} \mathrm{Fe}_{2} \mathrm{O}_{4}$ samples are given in Fig. 2. For both samples, the SEM images show homogeneous morphologies without any chemical contrast between the crystalline grains. This confirms that no secondary phase was observed outside the ferrite phases. The size distribution of the samples using image $J$ software shows average particle size of about $0.675 \mu \mathrm{m}$ and $0.853 \mu \mathrm{m}$ for the samples sintered at $900{ }^{\circ} \mathrm{C}$ and $1100{ }^{\circ} \mathrm{C}$, respectively.

The indexing of the XRD patterns was performed according to the cubic spinel structure in $F d \overline{3} m$ space group (Fig. 3). From the inset of Fig. 3, we can conclude that the lattice parameters change relatively with sintering temperature as the position of the most intense peak (311) exhibits a slight shift towards lower $(2 \theta)$ diffraction angle. To refine the 
structure of the samples using Rietveld method, we proposed the following cationic distribution for the composition $\mathrm{Ni}_{0.4} \mathrm{Cd}_{0.3} \mathrm{Zn}_{0.3} \mathrm{Fe}_{2} \mathrm{O}_{4}[\mathbf{5}, \mathbf{1 6}, \mathbf{1 7 ]}$ :

$\left(\mathrm{Cd}_{0.3}^{2+} \mathrm{Zn}_{0.3}^{2+} \mathrm{Fe}_{0.4}^{3+}\right)_{A}\left[\mathrm{Ni}_{0.4}^{2+} \mathrm{Fe}_{1.6}^{3+}\right]_{B} \mathrm{O}_{4}^{2-}$

The structural refinement for the samples is illustrated in Fig. 4, and the structural parameters obtained after refinement are listed in Table 1. With increasing the sintering temperature, the lattice parameter and cell volume increase monotonously. This behavior agrees well with that found in other works $[18,19]$. Likewise, the oxygen positions values are characteristics of the spinel structure $[20,21]$. As an act of comparison, one can note that the obtained values of the lattice constant for $\mathrm{Ni}_{0.4} \mathrm{Cd}_{0.3} \mathrm{Zn}_{0.3} \mathrm{Fe}_{2} \mathrm{O}_{4}$ samples are higher than those obtained for the undoped compound $\mathrm{Ni}_{0.7} \mathrm{Zn}_{0.3} \mathrm{Fe}_{2} \mathrm{O}_{4}[\mathbf{5}, \mathbf{2 2}]$. Obviously the substitution of $\mathrm{Cd}$ instead $\mathrm{Ni}$ in $\mathrm{Ni}_{0.7} \mathrm{Zn}_{0.3} \mathrm{Fe}_{2} \mathrm{O}_{4}$ sample causes the increase of its lattice parameters, in agreement with the bigger ionic radius of $\mathrm{Cd}\left(r_{\mathrm{Cd}^{2+}}{ }^{2+} 0.95 \AA\right)$ compared to that for $\mathrm{Ni}\left(r_{\mathrm{Ni}^{2+}}=0.69 \AA\right)$ [23]. The same result is observed by M.R. Patil et al. for $\mathrm{Ni}_{0.5-\mathrm{x}} \mathrm{Cd}_{\mathrm{x}} \mathrm{Zn}_{0.5} \mathrm{Fe}_{2} \mathrm{O}_{4}$ system $[13,14]$, and it is in agreement with the results found for $\mathrm{Ni}_{1-\mathrm{x}} \mathrm{Cd}_{\mathrm{x}} \mathrm{Fe}_{2} \mathrm{O}_{4}$ system [24]. The X-ray density was calculated as [5]:

$d_{x}=\frac{8 M}{N a^{3}}$

where $M$ is the molecular weight, $a$ is the lattice constant and $N$ is the Avogadro number. In Table 1 the $d_{x}$ values decrease with sintering temperature. The grain size of the samples was estimated using the following Scherer formula [25]:

$D_{X R D}=\frac{0.9 \lambda}{\beta \cos (\theta)}$

where $\lambda$ is the employed $\mathrm{X}$-ray wavelength, $\theta$ is the diffraction angle for the most intense peak (3 11 1), and $\beta$ its full width at half maximum (FWHM). The results show an increase of the grain size with sintering temperature (see Table 1). This agrees well with other previously works $[18,19]$. The estimated grains size values from XRD data are significantly lower than those obtained from SEM micrographs. This difference is due to the fact that each particle 
analyzed by SEM is made up of a multitude of smaller grains, and as the X-rays have a much higher resolution than that of the SEM, the size estimated from XRD is much smaller than that obtained from SEM [26].

Magnetic hysteresis loop recorded at room temperature at $-10 \mathrm{kOe} \leq H \leq+10 \mathrm{kOe}$ magnetic-field ranges for samples sintered at $900^{\circ} \mathrm{C}$ and $1100^{\circ} \mathrm{C}$ is shown in Fig. 5. For both samples, the $M(H)$ curves are characterized by a nonlinear behavior marked by a pointed raise for low $H$-values, and an affinity to saturation in the case of high $H$-values reflecting a ferromagnetic behavior. The maximum magnetization $\left(M_{s}\right)$ increases from $65.99 \mathrm{emu} / \mathrm{g}$ for sample sintered at $900{ }^{\circ} \mathrm{C}$ to $77.29 \mathrm{emu} / \mathrm{g}$ for the one sintered at $1100{ }^{\circ} \mathrm{C}$. In addition, the remanence $\left(M_{r}\right)$ and the coercivity $\left(H_{c}\right)$ decrease from $7.69 \mathrm{emu} / \mathrm{g}$ and 131.84 Oe for sample sintered at $900{ }^{\circ} \mathrm{C}$ to $4.34 \mathrm{emu} / \mathrm{g}$ and 74.59 Oe for sample sintered at $1100{ }^{\circ} \mathrm{C}$. It can be observed that $H_{c}$ and $M_{r}$ values are very low, so we can consider the prepared samples as magnetically soft ferrites. The obtained magnetic constants offer to these samples the possible use in some interesting technological applications such as induction cores, transformers, recording heads, microwave devices, magnetic shielding, and spintronics devices [27]. The $M_{s}$-values obtained for both samples are higher than those found by A.A. Birajdar et al. for the undoped sample $\mathrm{Ni}_{0.7} \mathrm{Zn}_{0.3} \mathrm{Fe}_{2} \mathrm{O}_{4}[22,28]$. This is in excellent accord with the results found for $\mathrm{Ni}_{1-\mathrm{x}} \mathrm{Cd}_{\mathrm{x}} \mathrm{Fe}_{2} \mathrm{O}_{4}$ systems $[24,29]$. We can notice that the $M_{s^{-}}$-values were affected by the augmantation of sintering temperature. This can be related to the gradual rise in the grain size $[30,31]$. Also the decline of $H_{c}$ values could be explained by the rise of the grains size. The decline in coercivity with increasing grains size can occur due to the two different mechanisms. Firstly, it may occur as the particle sizes become large enough to sustain a domain wall. In this situation the magnetization reversal would occur via domain wall motion and consequently a lower coercivity would be observed [32]. Secondly, it may be due to the varying role of the surface and the observed bulk anisotropies as the size is increased. With 
increasing grains size, the role of the surface and its associated anisotropy energy is decreased since the surface becomes much less dominant compared to the core of the nanocrystals [32, 33]. This leads to lower coercivity for sample sintered at $1100^{\circ} \mathrm{C}$ (which has a larger grain size) compared to the one sintered at $900^{\circ} \mathrm{C}$ (which has a less grain size).

The variations of the conductivity $(\sigma)$ as a function of both frequency and temperature for $\mathrm{Ni}_{0.4} \mathrm{Cd}_{0.3} \mathrm{Zn}_{0.3} \mathrm{Fe}_{2} \mathrm{O}_{4}$ ferrites sintered at $900^{\circ} \mathrm{C}$ to $1100^{\circ} \mathrm{C}$ are presented in Fig. 6. These curves allow as understanding the conduction mechanism for our samples. To modelize the $\sigma$ values, we used the following Jonscher power law [34]:

$\sigma_{t o t}=\sigma_{d c}+A \omega^{s}$

where, $\sigma_{d c}$ is the $d c$ conductivity, $A$ and $s$ are the pre-exponential and exponent factors, respectively. Fig. 6 reveals a good agreement between the theoretical and experimental curves. All adjustment parameters are listed in Table 2 for both samples. In particular, we can see a gradual increase of the $s$-exponent with temperature. Such a behavior corresponds to a thermally activated process. In addition, all the $s$-values are greater than unity. This means, according to the Funke criterion [35], that the electrons hopping in the prepared samples occurs between neighboring sites. The behavior of $n$ observed for our samples is in good agreement with the results found in some previous works $[36,37]$. It can be noticeable also that the $s$-values for the sample sintered at $1100{ }^{\circ} \mathrm{C}$ are all bigger than those resulted from the sample sintered at $900{ }^{\circ} \mathrm{C}$. This is an indication that the electron hopping increases with the increase of sintered temperature. In the other side, at low frequency region, the $d c$ conductivity values increase with increasing temperature (see Table 1) which indicates that our samples exhibits a semiconductor behaviors in all temperature range. The semiconductorlike nature is also observed for other Ni-Cd-Zn ferrites $[\mathbf{1 3}, \mathbf{1 4}]$. From Table 1, we can also see a gradually increases of the $d c$ conductivity as sintering temperatures increase. This result indicates that the conduction process is more activated for sample sintered at $1100{ }^{\circ} \mathrm{C}$ than the 
one sintered at $900{ }^{\circ} \mathrm{C}$. This increase in the $d c$ conductivity can be attributed to the increase of grain size with sintering temperature due to the fact that samples with small grains consist more number of grain boundaries then grains. The grain boundaries are the regions of mismatch between the energy states of adjacent grains and hence act as barriers to the flow of electrons [38]. Due to these size effects the $d c$ conductivity values for sample sintered at $1100{ }^{\circ} \mathrm{C}$ are higher than those of sample sintered at $900{ }^{\circ} \mathrm{C}$. Fig.7 demonstrates the $d c$ conductivity behaviors of the two samples with temperature which gives an Arrhenius plot by following this equation [39]:

$\sigma_{d c}=\sigma_{0} \exp \left(-\frac{E_{d c}}{k_{B} T}\right)$

where $\sigma_{0}$ is a pre-exponential factor, $E_{d c}$ is the activation energy, $T$ is the temperature, and $k_{B}$ is the Boltzmann constant. It could be clear from Fig.7, which reveals the linear variation between $\operatorname{Ln}\left(\sigma_{d c}\right)$ and $(1000 / T)$, that heating activates the conductivity of samples. The $E_{d c}$ values expected from the linear fit plots using Eq. (4) are found as $\left(E_{d c}=0.371 \mathrm{eV}\right.$ for sample sintered at $\left.900{ }^{\circ} \mathrm{C}\right)$ and $\left(E_{d c}=0.337 \mathrm{eV}\right.$ for sample sintered at $\left.1100{ }^{\circ} \mathrm{C}\right)$. The decrease of the activation energy is in excellent correlation with the results found in Ref. [40]. On the other hand, the values of the activation energies are lower than those found for other ferrite systems [41-44], which shows that our materials are good conductors.

Fig. 8 indicates the behaviors of real part of modulus $\left(M^{\prime}\right)$ for $\mathrm{Ni}_{0.4} \mathrm{Cd}_{0.3} \mathrm{Zn}_{0.3} \mathrm{Fe}_{2} \mathrm{O}_{4}$ ferrites sintered at $900^{\circ} \mathrm{C}$ to $1100^{\circ} \mathrm{C}$ vs. frequency and temperature. In the low frequency region, it is observed that $M^{\prime}$ values are very small for both samples. This confirms that the electrode polarization makes a negligible contribution in the materials [45]. With increasing frequency, a continuous increase of $M^{\prime}$ values was observed, and the values tend to saturate at a maximum asymptotic value in the high frequency region. This might be because of the short range mobility of charge carriers $[46,47]$. Fig. 9 indicates the behaviors of the imaginary component of modulus for $\mathrm{Ni}_{0.4} \mathrm{Cd}_{0.3} \mathrm{Zn}_{0.3} \mathrm{Fe}_{2} \mathrm{O}_{4}$ ferrites sintered at $900^{\circ} \mathrm{C}$ to $1100^{\circ} \mathrm{C}$. It is 
observable, that $\left(M^{\prime \prime}\right)$ has the similar profile for each temperature. In fact, at the beginning the $\left(M^{\prime \prime}\right)$ increases with increasing frequency until having an optimal value at $\left(f_{M^{\prime \prime}}^{\max }\right)$. Then, with increasing frequency the $M^{\prime \prime}(f)$ values decrease. The positions of the maximums move to higher frequency region depending on the increase of the temperature. This proposes that the relaxation process of the samples is related to the elevation of temperature. The $M^{\prime \prime}(f)$ values were well fitted using the Bergman proposed Kohlrausch, Williams and Watts (KWW) function as follows [48]:

$M^{\prime \prime}=M_{\max }^{\prime \prime} /\left[1-\beta+\left(\frac{\beta}{1+\beta}\right)\left(\beta\left(\frac{f_{\max }}{f}\right)+\left(\frac{f}{f_{\max }}\right)^{\beta}\right)\right]$

where $M_{\text {max }}^{\prime \prime}$ is the peak maxima and $f_{\text {max }}$ its corresponding frequency, and $\beta$ is the stretching factor $(0<\beta<1)$. In Table 3, we summarize the results of fitting parameters using Eq. (5). According to this table, two important points can be taken into account: the first one is that the $\beta$-values are less than unity which demonstrates the non-Debye nature of the samples [49]; and the second one that these values increase with increasing sintering temperature which is related to the increase of the grain size [50]. In table 3 we have grouped the values of the relaxation frequency $\left(f_{\max }\right)$ that allow us to calculate the relaxation time $\left(\tau_{M^{\prime \prime}}\right)$ through this equation:

$\tau_{M^{\prime \prime}}=1 / 2 \pi f_{\max }$

Fig. 10 expose the reverse temperature variation of the relaxation time $\left(\tau_{M^{\prime \prime}}\right)$ for $\mathrm{Ni}_{0.4} \mathrm{Cd}_{0.3} \mathrm{Zn}_{0.3} \mathrm{Fe}_{2} \mathrm{O}_{4}$ ferrites sintered at $900^{\circ} \mathrm{C}$ to $1100^{\circ} \mathrm{C}$. The Arrhenius relation can be also used to modelize the temperature reliance of the relaxation time as [51]:

$\tau_{M^{n}}=\tau_{o} \exp \left(\frac{E_{M "}}{k_{B} T}\right)$

with $k_{B}$ is the Boltzmann constant, $T$ is the temperature, $E_{M^{n}}$ is the activation energy and $\tau_{0}$ is the pre-exponential factor. The $E_{M^{n}}$ values predictable from the linear fit of the curves are equal to $0.369 \mathrm{eV}$ (for simple sintered at $900{ }^{\circ} \mathrm{C}$ ) and $0.329 \mathrm{eV}$ (for simple sintered at 
$\left.1100{ }^{\circ} \mathrm{C}\right)$. These values are very nearby to those deduced from the $d c$ conductivity $\left(E_{d c}\right)$, and this is an indication that the relaxation phenomenon as well as the electrical conductivity contribute to the same defect.

Fig. 11 displays the complex impedance curves (named Nyquist diagrams, i.e. Z" vs. $Z^{\prime}$ plots) at different temperatures for $\mathrm{Ni}_{0.4} \mathrm{Cd}_{0.3} \mathrm{Zn}_{0.3} \mathrm{Fe}_{2} \mathrm{O}_{4}$ ferrites sintered at $900^{\circ} \mathrm{C}$ and $1100^{\circ} \mathrm{C}$. It is obvious in Fig. 11 that, for all the temperatures, the impedance spectra shows semicircle arcs whose maxima and diameters decline with increasing temperature. The intersection with real axis of these semicircles at low frequencies (right intersect) is ascribed to the total resistance $\mathrm{R}_{\mathrm{T}}=\mathrm{R}_{\mathrm{g}}+\mathrm{R}_{\mathrm{gb}}$, with $R_{g}$ and $R_{g b}$ are the grain and grain boundary resistances, respectively [36]. On the other hand, the impedance response of grain dominates at high frequencies, so $R_{g}$ can be deduced from the left intersect of the semicircles with real axis. The grain boundary resistance values are then given as $\mathrm{R}_{\mathrm{gb}}=\mathrm{R}_{\mathrm{T}}-\mathrm{R}_{\mathrm{g}}$. From the impedance spectra represented in Fig. 11, it is clear that the grain resistance $R_{g}$ is too weak and the grain boundary resistance is approximately equal to $R_{T}$. So, we can conclude that the conduction mechanism of the samples is achieved basically of the grain boundary contribution. To prove this observation, it was obligatory to modelize the Nyquist diagrams. The suitable equivalent circuit configuration is of the type of $\left(\mathrm{R}_{\mathrm{g}} / / \mathrm{C}_{\mathrm{g}}+\mathrm{R}_{\mathrm{gb}} / / \mathrm{C}_{\mathrm{gb}}\right)$ [52] (see the insets of Fig. 11). In this configuration, $C_{g}$ and $C_{g b}$ modelize respectively the grain and grain boundary capacitances. The $R_{g}, C_{g}, R_{g b}$ and $C_{g b}$ parameters have been evaluated for each temperature by modeling the Nyquist diagrams using Zview software and they are listed in Table 4. It could be noted that the fitting is in harmony with the results found during experimentation (red solid lines in Fig. 11). In fact, samples behave like semiconductor seen that the grain boundary resistance decreases with the increase of temperature. Moreover, the estimated values of $R_{g b}$ are more important than $R_{g}$ confirming that the conduction process in the samples is basically related to the grain boundary apport as it is cited previously. In the 
other hand, the obtained $R_{g}$ as well as $R_{g b}$ values are higher for the sample sintered at $900{ }^{\circ} \mathrm{C}$ than for the one sintered at $1100{ }^{\circ} \mathrm{C}$.

\section{Conclusion}

To conclude, we have investigated microstructural, magnetic and electrical properties of $\mathrm{Ni}_{0.4} \mathrm{Cd}_{0.3} \mathrm{Zn}_{0.3} \mathrm{Fe}_{2} \mathrm{O}_{4}$ ferrites prepared using sol gel method at different sintering temperatures. The rise of sintering temperature allows not only to the rise of the lattice constant and grain size, but also to the magnetization and the electrical conductivity of these ferrites. From electrical modulus analysis, we prove the presence of a relaxation phenomenon with non-Debye nature for the samples. The estimated values of activation energies from the relaxation time and the dc-conductivity are very close. The study of the Nyquist plots using the suitable equivalent circuit shows that $R_{g}$ and $R_{g b}$ values are lower for sample sintered at $1100^{\circ} \mathrm{C}$ than those for the one sintered at $900^{\circ} \mathrm{C}$.

\section{Acknowledgements}

This work was supported by the Deanship of Scientific Research at Prince Sattam Bin Abdulaziz University under the research Project Number 2017/01/7373. 


\section{References}

[1] Y.Y. Meng, Z.W. Liu, H.C. Dai, H.Y. Yu, D.C. Zeng, S. Shukla, et al. Powder Technol. 229 (2012) 270.

[2] H. Igarash, K. Okazaki, J. Am. Ceram. Soc. 60 (1977) 51.

[3] K. Kulikowski, J. Magn. Magn. Mater.41 (1984) 56.

[4] R.V. Mangalaraj, S. Ananthakumar, P. Manohar, F.D. Gnanam, Mater. Lett. 57 (2003) 1151 .

[5] M.S. Anwar, F. Ahmed, B.H. Koo, Acta Materialia 71 (2014) 100.

[6] A.C.F.M. Costa, M.R. Morelli, RHGA Kiminami, J. Mater. Sci. 42 (2007) 779.

[7] P. Gao, X. Hua, V. Degirmenci, D. Rooney, M. Khraisheh, R. Pollard, R.M. Bowman, E.V. Rebrov, J. Magn. Magn. Mater. 348 (2013) 44.

[8] A.T. Raghavender, N. Biliškov, Ž. Skoko, Mater. Lett. 65 (2011) 677.

[9] A. Ghasemi, J. Magn. Magn. Mater. 360 (2014) 41.

[10] B.R. Babu, B.B.V.S.V. Prasad, M.S.R. Prasad, Mod. Phys. Lett. B. 28 (2014) 1450244.

[11] M.M. Mallapur, P.A. Shaikh, R.C. Kambale, H.V. Jamadar, P.U. Mahamuni, B.K. Chougule, J. Alloys Compd. 479 (2009) 797.

[12] U.B. Gawas, M.M. Kothawale, R. Pednekar, S.S. Meena, N.K. Prasad, S.K. Alla, J. Supercond. Nov. Magn. 30 (2017) 1287.

[13] M.R. Patil, M.K. Rendale, S.N. Mathad, R.B. Pujar, Int. J Self-Propag. High-Temp. Synth. 24 (2015) 241.

[14] M.R. Patil, M.K. Rendale, S.N. Mathad, R.B. Pujar Inorg Nano-Met. Chem. 47 (2017) 1145 .

[15] H.M. Rietveld, J. Appl. Cryst. 2 (1969) 65.

[16] M.A. Hakim, S.K. Nath, S.S. Sikder, K.H. Maria, J. Phys. Chem. Solids. 74 (2013) 1316.

[17] K.S. Lohar, S.M. Patange, M.L. Mane , Sagar E. Shirsath, J. Mol. Struct. 1032 (2013) 105.

[18] R.P. Patil , P.P. Hankare , K.M. Garadkar, R. Sasikala, J. Alloys Compd. 523 (2012) 66.

[19] M. Rahimi, P. Kameli, M. Ranjbar, H. Salamati, J. Nanopart. Res. 15 (2013) 1865.

[20] N. Pailhé, A. Wattiaux, M. Gaudon, A. Demourgues. J. Solid State Chem. 181 (2008) 1040 .

[21] K. Verma, A. Kumar, D. Varshney. J. Alloys Compd. 526 (2012) 91.

[22] A.A. Birajdar, S.E. Shirsath, R.H. Kadam, M.L. Mane, D. R. Mane, A. R. Shitre, J. Appl. Phys. 112 (2012) 053908.

[23] R.D. Shannon, Acta Crystallogr. A 32 (1976) 751. 
[24] M.B. Shelar , P.A. Jadhav, D.R. Patil, B.K. Chougule, Vijaya Puri, J. Magn. Magn. Mater. 322 (2010) 3355.

[25] M.A. Ahmed, H.H. Afify, I.K. El Zawawia, A.A. Azab, J. Magn. Magn. Mater. 324 (2012) 2199.

[26] S. Hcini, S. Zemni, A. Triki, H. Rahmouni, M. Boudard, J. Alloys Compd. 509 (5) 1394.

[27] H. Shokrollahi, K. Janghorban, J. Mater. Process. Tech. 189 (2007) 1.

[28] A.A. Birajdar, Sagar E. Shirsath, R.H. Kadam, S.M. Patange, K.S. Lohar, D.R. Mane d, A.R. Shitre, J. Alloys Compd. 512 (2012) 316.

[29] A.K. Nikumbh, A.V. Nagawade, G.S. Gugale, M.G. Chaskar, P.P. Bakare, J. Mater. Sci. 37 (2002) 637.

[30] Y.M.Z. Ahmed, Ceram. Int. 36 (2010) 969.

[31] S.B. Waje, M. Hashim, I. Ismail, J. Magn. Magn. Mater. 323 (2011) 1433.

[32] K. Maaz, S. Karim, A. Mumtaz, S.K. Hasanain, J. Liu, J.L. Duan, J. Magn. Magn. Mater. 321 (2009) 1838.

[33] M. Artus, L.B. Tahar, F. Herbst, L. Smiri, F. Villain, N. Yaacoub, J.M. Grenèche, S. Ammar, F. Fiévet, J. Phys.: Condens. Matter 23 (2011) 506001.

[34] N. Ortega, A. Kumar, P. Bhattacharya, S.B. Majumder, R.S. Katiyar, Phys. Rev. B 77 (2008) 014111.

[35] K. Funke, Prog. Solid State Chem. 22 (1993) 111.

[36] M.H. Dhaou, S. Hcini, A. Mallah, M.L. Bouazizi, A. Jemni, Appl. Phys. A 123 (2017) 8. [37] A. Selmi, S. Hcini, H. Rahmouni, A. Omri, M.L. Bouazizi, A. Dhahri, Phase Transitions 90 (2017) 942.

[38] K.M. Batoo, S. Kumar, C.G. Lee, Alimuddin, Curr. Appl. Phys. 9 (2009) 1072.

[39] S.K. Mandal, S. Singh, P. Dey, J.N. Roy, P.R. Mandal, T.K. Nath, J. Alloys Compd. 656 (2016) 887.

[40] A. Sutka, S. Lagzdina, G. Mezinskis, A. Pludons, I. Vitina, L. Timma, IOP Conf. Ser.: Mater. Sci. Eng. 25 (2011) 012019.

[41] M.S.R. Prasad, K.V. Ramesh, B.R. Babu, K. Trinath, Indian J. Phys 90 (2016) 417. [42] A. Humaira, M. Asghari, J. Phys: Conf. Ser. 439 (2013) 012014.

[43] S. Bhukal, S. Mor, S. Bansal, J. Singh, S. Singhal, J. Mol. Struct. 1071 (2014) 95.

[44] S. Bhukal, T. Namgyal, S. Mor, S. Bansal, S. Singhal, J. Mol. Struct. 1012 (2012) 162.

[45] N.H. Vasoya, P.K. Jha, K.G. Saija, S.N. Dolia, K.B. Zankat, and K.B. Modi. J. Electron. Mater, 45 (2016) 917.

[46] S. Saha, T.P. Sinha, Phys. Rev. B 65 (2005) 1341. 
[47] K.P. Padmasree, D.D. Kanchan, A.R. Kulkami, Solid State Ion. 177, (2006) 475.

[48] R. Bergman, J. Appl. Phys. 88 (2000) 1356.

[49] K.S. Rao, P.M. Krishna, D.M. Prasad, D. Gangadharudu, J. Mater. Sci. 42 (2007) 4801.

[50] N. Sivakumar, A. Narayanasamy, C.N. Chinnasamy, B. Jeyadevan, J. Phys.: Condens. Matter 19 (2007) 386201.

[51] N. Singh, A. Agarwal, S. Sanghi. Curr. Appl. Phys. 11 (2011) 783.

[52] K.M. Batoo, Physica B 406 (2011) 382. 


\section{Tables}

Table 1: Structural refinement parameters for $\mathrm{Ni}_{0.4} \mathrm{Cd}_{0.3} \mathrm{Zn}_{0.3} \mathrm{Fe}_{2} \mathrm{O}_{4}$ ferrites. $B_{\text {iso }}$ : is the isotropic Debye-Waller factor, $d_{(\mathrm{M} 8 \mathrm{a}-\mathrm{O})}$ and $d_{(\mathrm{M} 16 \mathrm{~d}-\mathrm{O})}$ : cation - oxygen distances, $\theta_{(\mathrm{M} 8 \mathrm{a}-\mathrm{O}-\mathrm{M} 8 \mathrm{a})}$ and $\theta_{(\mathrm{M} 8 \mathrm{a}-\mathrm{O}-\mathrm{M} 16 \mathrm{~d})}$ : cation-oxygen-cation bond angles (M denotes cations in $8 \mathrm{a}$ and $16 \mathrm{~d}$ sites, respectively), $d_{x}$ : X-ray density, $D_{X R D}$ : grains size estimated from the XRD peaks. Agreement factors of profile $R_{p}$, weighted profile $R_{w p}$, and structure $R_{F} \cdot \chi^{2}$ : the goodness of fit. The numbers in parentheses are estimated standard deviations to the last significant digit.

Table 2: Fitting parameters obtained using Jonscher power law for $\mathrm{Ni}_{0.4} \mathrm{Cd}_{0.3} \mathrm{Zn}_{0.3} \mathrm{Fe}_{2} \mathrm{O}_{4}$ ferrites.

Table 3: Modulus parameters obtained using Eq. (5) for $\mathrm{Ni}_{0.4} \mathrm{Cd}_{0.3} \mathrm{Zn}_{0.3} \mathrm{Fe}_{2} \mathrm{O}_{4}$ ferrites.

Table 4: Impedance parameters of electrical equivalent circuit for $\mathrm{Ni}_{0.4} \mathrm{Cd}_{0.3} \mathrm{Zn}_{0.3} \mathrm{Fe}_{2} \mathrm{O}_{4}$ ferrites. 


\section{Table 1}

\begin{tabular}{|c|c|c|c|c|c|}
\hline \multirow{2}{*}{$\begin{array}{l}\mathrm{Ni}_{0.4} \mathrm{Cd}{ }_{0.3} \mathrm{Zn}_{0.3} \mathrm{Fe}_{2} \mathrm{O}_{4} \\
\text { Snaco oroun }\end{array}$} & & & & \multirow[t]{2}{*}{$900^{\circ} \mathrm{C}$} & \multirow[t]{2}{*}{$1100^{\circ} \mathrm{C}$} \\
\hline & & $F d \overline{3} m$ & & & \\
\hline \multirow[t]{2}{*}{ Cell parameters } & $a(\stackrel{\circ}{)})$ & & & $8.4345(4)$ & $8.4371(4)$ \\
\hline & $V\left(\AA^{3}\right)$ & & & $600.04(4)$ & $600.60(4)$ \\
\hline \multirow[t]{15}{*}{ Atoms } & Cd/Zn/FeI & Wyckoff positions & & $8 \mathrm{a}$ & $8 \mathrm{a}$ \\
\hline & & Site smmetry & & $-43 m$ & $-43 m$ \\
\hline & & Atomic positions & $x=y=z$ & $1 / 8$ & $1 / 8$ \\
\hline & & Occupancy factors & & $0.3 / 0.3 / 0.4$ & $0.3 / 0.3 / 0.4$ \\
\hline & & $\boldsymbol{B}_{\text {iso }}\left(\AA^{2}\right)$ & & $0.84(1)$ & $0.55(1)$ \\
\hline & $\mathrm{Ni} / \mathrm{Fe} 2$ & Wyckoff positions & & $16 d$ & $16 \mathrm{~d}$ \\
\hline & & Site smmetry & & $-3 m$ & $-3 m$ \\
\hline & & Occupancy factors & & $0.4 / 1.6$ & $0.4 / 1.6$ \\
\hline & & Atomic positions & $x=y=z$ & $1 / 2$ & $1 / 2$ \\
\hline & & $B_{\text {iso }}\left(\AA^{2}\right)$ & & $1.49(1)$ & $1.11(1)$ \\
\hline & $O$ & Wyckoff positions & & $32 \mathrm{e}$ & $32 \mathrm{e}$ \\
\hline & & Site smmetry & & $3 \mathrm{~m}$ & $3 \mathrm{~m}$ \\
\hline & & Atomic positions & $x=y=z$ & $0.2531(5)$ & $0.2530(5)$ \\
\hline & & Occupancy factors & & 4 & 4 \\
\hline & & $\boldsymbol{B}_{\text {iso }}\left(\AA^{2}\right)$ & & $2.24(2)$ & $2.05(5)$ \\
\hline \multirow[t]{6}{*}{ Structural parameters } & \multicolumn{2}{|l|}{$d_{(\mathrm{MBa}-\mathrm{O})}(\stackrel{\AA}{\AA})$} & & $1.871(4)$ & $1.871(4)$ \\
\hline & \multicolumn{2}{|l|}{$d_{(\mathrm{M} 16 \mathrm{~d}-0)}(\stackrel{\AA}{A})$} & & $2.083(4)$ & $2.084(4)$ \\
\hline & \multicolumn{2}{|c|}{$\theta_{\text {(M16d-O- M16d) }}\left({ }^{\circ}\right)$} & & $91.43(2)$ & $91.38(2)$ \\
\hline & \multicolumn{2}{|c|}{$\theta_{(\text {M8a -O- M16d) }}\left({ }^{\circ}\right)$} & & $124.25(2)$ & $124.28(2)$ \\
\hline & \multicolumn{2}{|l|}{$d_{x}\left(\mathrm{~g} / \mathrm{cm}^{3}\right)$} & & 5.5904 & 5.5851 \\
\hline & \multicolumn{2}{|l|}{$D_{X R D}(n m)$} & & 131 & 160 \\
\hline \multirow[t]{4}{*}{ Agreement factors } & \multicolumn{2}{|l|}{$R_{p}(\%)$} & & 18.1 & 18.3 \\
\hline & \multicolumn{2}{|l|}{$\boldsymbol{R}_{w p}(\%)$} & & 25.9 & 25.8 \\
\hline & \multicolumn{2}{|l|}{$R_{F}(\%)$} & & 11.8 & 11.0 \\
\hline & \multicolumn{3}{|l|}{$\chi^{2}(\%)$} & 1.18 & 1.17 \\
\hline
\end{tabular}


Table 2

\begin{tabular}{lllllllll}
\hline $\boldsymbol{T}(\boldsymbol{K})$ & $\mathbf{9 0 0}^{\circ} \mathbf{C}$ & \multicolumn{7}{c}{$\mathbf{1 1 0 0}^{\circ} \mathbf{C}$} \\
\cline { 2 - 8 } & $\boldsymbol{\sigma}_{d c} \times \mathbf{1 0}^{-4}(\mathbf{S} / \mathbf{m})$ & $\boldsymbol{A} \times \mathbf{1 0}^{-\mathbf{1 4}}$ & $\boldsymbol{S}$ & $\chi^{2}$ & $\boldsymbol{\sigma}_{\boldsymbol{d c}} \times \mathbf{1 0}^{-4}(\mathbf{S} / \mathbf{m})$ & $\boldsymbol{A} \times \mathbf{1 0}^{-\mathbf{1 4}}$ & $\boldsymbol{s}$ & $\chi^{2}$ \\
\hline $\mathbf{3 0 0}$ & 4 & 28.071 & 1.504 & 0.999 & 32 & 3.293 & 1.853 & 0.999 \\
$\mathbf{3 4 0}$ & 13 & 5.891 & 1.644 & 0.999 & 174 & 2.731 & 1.8854 & 0.996 \\
$\mathbf{3 8 0}$ & 56 & 4.626 & 1.719 & 0.995 & 640 & 1.357 & 1.9164 & 0.995 \\
$\mathbf{4 2 0}$ & 188 & 4.185 & 1.786 & 0.998 & 1819 & 1.107 & 1.9532 & 0.996 \\
$\mathbf{4 6 0}$ & 436 & 5.319 & 1.802 & 0.999 & 3054 & 1.043 & 1.9855 & 0.997 \\
$\mathbf{5 0 0}$ & 1137 & 3.220 & 1.843 & 0.999 & 6104 & 0.192 & 2.107 & 0.994 \\
\hline
\end{tabular}


Table 3:

\begin{tabular}{|c|c|c|c|c|c|c|c|c|}
\hline \multirow{2}{*}{$\begin{array}{c}\boldsymbol{T} \mathbf{( K )} \\
3 \\
4 \\
5\end{array}$} & \multicolumn{4}{|l|}{$900^{\circ} \mathrm{C}$} & \multicolumn{4}{|l|}{$1100^{\circ} \mathrm{C}$} \\
\hline & $M_{\max }^{\prime \prime}\left(\times 10^{-4}\right)$ & $\beta$ & $f_{\max }(\boldsymbol{H} z)$ & $\chi^{2}$ & $M_{\max }^{\prime \prime}\left(\times 10^{-4}\right)$ & $\beta$ & $f_{\max }(\boldsymbol{H z})$ & $\chi^{2}$ \\
\hline $\begin{array}{r}300 \\
7\end{array}$ & 4.7 & 0.990 & 6755 & 0.999 & 2.6 & 0.998 & 33639 & 0.998 \\
\hline $34 \theta$ & 4 & 0.992 & 18032 & 0.999 & 2.4 & 0.995 & 157431 & 0.998 \\
\hline $38 \theta$ & 3.2 & 0.967 & 70179 & 0.993 & 2.4 & 0.971 & 589859 & 0.997 \\
\hline $4 \overline{2} \frac{1}{2}$ & 3.1 & 0.949 & 222661 & 0.998 & 2 & 0.953 & 1408746 & 0.998 \\
\hline 460 & 3.2 & 0.932 & 540833 & 0.996 & 1.6 & 0.937 & 1990634 & 0.999 \\
\hline $\begin{array}{r}\mathbf{5 \theta 0} \\
16\end{array}$ & 3.2 & 0.855 & 1503967 & 0.999 & 1.5 & 0.869 & 4116678 & 0.998 \\
\hline
\end{tabular}




\section{Table 4}

\begin{tabular}{|c|c|c|c|c|c|c|c|c|}
\hline \multirow{2}{*}{$\begin{array}{c}\boldsymbol{T}_{3}^{2}(\boldsymbol{K}) \\
4 \\
5\end{array}$} & \multicolumn{4}{|l|}{$900^{\circ} \mathrm{C}$} & \multicolumn{4}{|l|}{$1100^{\circ} \mathrm{C}$} \\
\hline & $R_{g}(\Omega)$. & $C_{g} \times 10^{-15}(\mathrm{~F})$ & $R_{g b}\left(\Omega_{.}\right)$ & $C_{g b} \times 10^{-10}(F)$ & $R_{g}(\Omega)$. & $C_{g} \times 10^{-15}(F)$ & $R_{g b}\left(\Omega_{.}\right)$ & $C_{g b} \times 10^{-10}(\mathrm{~F})$ \\
\hline 300 & 200 & 2 & 286060 & 0.82 & 80 & 8 & 45427 & 1.06 \\
\hline $\begin{array}{c}340 \\
9\end{array}$ & 195 & 5 & 105560 & 0.83 & 70 & 14 & 8864 & 6.59 \\
\hline $\begin{array}{l}380 \\
11\end{array}$ & 180 & 11 & 26690 & 3.06 & 55 & 20 & 2428 & 20.02 \\
\hline $\begin{array}{l}1420 \\
13\end{array}$ & 130 & 17 & 8203 & 10.99 & 42 & 26 & 834 & 70.31 \\
\hline $\begin{array}{l}\mathbf{4 6 0} \\
15 \\
15\end{array}$ & 100 & 25 & 3563 & 50.81 & 40 & 32 & 480 & 70.52 \\
\hline $\begin{array}{l}500 \\
17\end{array}$ & 70 & 31 & 1330 & 80.80 & 43 & 41 & 220 & 100.31 \\
\hline
\end{tabular}




\section{Figure captions}

Fig. 1: Different steps used in the sol-gel synthesis of $\mathrm{Ni}_{0.4} \mathrm{Cd}_{0.3} \mathrm{Zn}_{0.3} \mathrm{Fe}_{2} \mathrm{O}_{4}$ ferrites.

Fig. 2: Scanning electron micrographs and particle size distributions for $\mathrm{Ni}_{0.4} \mathrm{Cd}_{0.3} \mathrm{Zn}_{0.3} \mathrm{Fe}_{2} \mathrm{O}_{4}$ ferrites.

Fig. 3: XRD patterns of $\mathrm{Ni}_{0.4} \mathrm{Cd}_{0.3} \mathrm{Zn}_{0.3} \mathrm{Fe}_{2} \mathrm{O}_{4}$ ferrites. The peaks are indexed in $F d \overline{3} m$ space group. The inset shows the most intense peaks $\left(\begin{array}{lll}3 & 1 & 1\end{array}\right)$.

Fig. 4: XRD patterns with Rietveld refinement for $\mathrm{Ni}_{0.4} \mathrm{Cd}_{0.3} \mathrm{Zn}_{0.3} \mathrm{Fe}_{2} \mathrm{O}_{4}$ ferrites.

Fig. 5: Magnetic hysteresis loops measured at room temperature for $\mathrm{Ni}_{0.4} \mathrm{Cd}_{0.3} \mathrm{Zn}_{0.3} \mathrm{Fe}_{2} \mathrm{O}_{4}$ ferrites. Inset: Part of the curves near the origin showing remanence $\left(M_{r}\right)$ and coercivity $\left(H_{c}\right)$. Fig. 6: Conductivity vs. frequency at different temperatures with Jonscher power law fitting for $\mathrm{Ni}_{0.4} \mathrm{Cd}_{0.3} \mathrm{Zn}_{0.3} \mathrm{Fe}_{2} \mathrm{O}_{4}$ ferrites.

Fig. 7: $\mathrm{Ln}\left(\sigma_{d c}\right)$ vs. $(1000 / \mathrm{T})$ with Arrhenius relation fitting for $\mathrm{Ni}_{0.4} \mathrm{Cd}_{0.3} \mathrm{Zn}_{0.3} \mathrm{Fe}_{2} \mathrm{O}_{4}$ ferrites.

Fig. 8: Real part of electrical modulus vs. frequency at different temperatures for $\mathrm{Ni}_{0.4} \mathrm{Cd}_{0.3} \mathrm{Zn}_{0.3} \mathrm{Fe}_{2} \mathrm{O}_{4}$ ferrites.

Fig. 9: Imaginary part of electrical modulus vs. frequency at different temperatures fitted using KWW function for $\mathrm{Ni}_{0.4} \mathrm{Cd}_{0.3} \mathrm{Zn}_{0.3} \mathrm{Fe}_{2} \mathrm{O}_{4}$ ferrites.

Fig. 10: $\operatorname{Ln}\left(\tau_{M "}\right)$ vs. $(1000 / T)$ for $\mathrm{Ni}_{0.4} \mathrm{Cd}_{0.3} \mathrm{Zn}_{0.3} \mathrm{Fe}_{2} \mathrm{O}_{4}$ ferrites.

Fig. 11: Complex impedance spectra at different temperatures for $\mathrm{Ni}_{0.4} \mathrm{Cd}_{0.3} \mathrm{Zn}_{0.3} \mathrm{Fe}_{2} \mathrm{O}_{4}$ ferrites. The inset shows the proposal electrical equivalent circuit. 


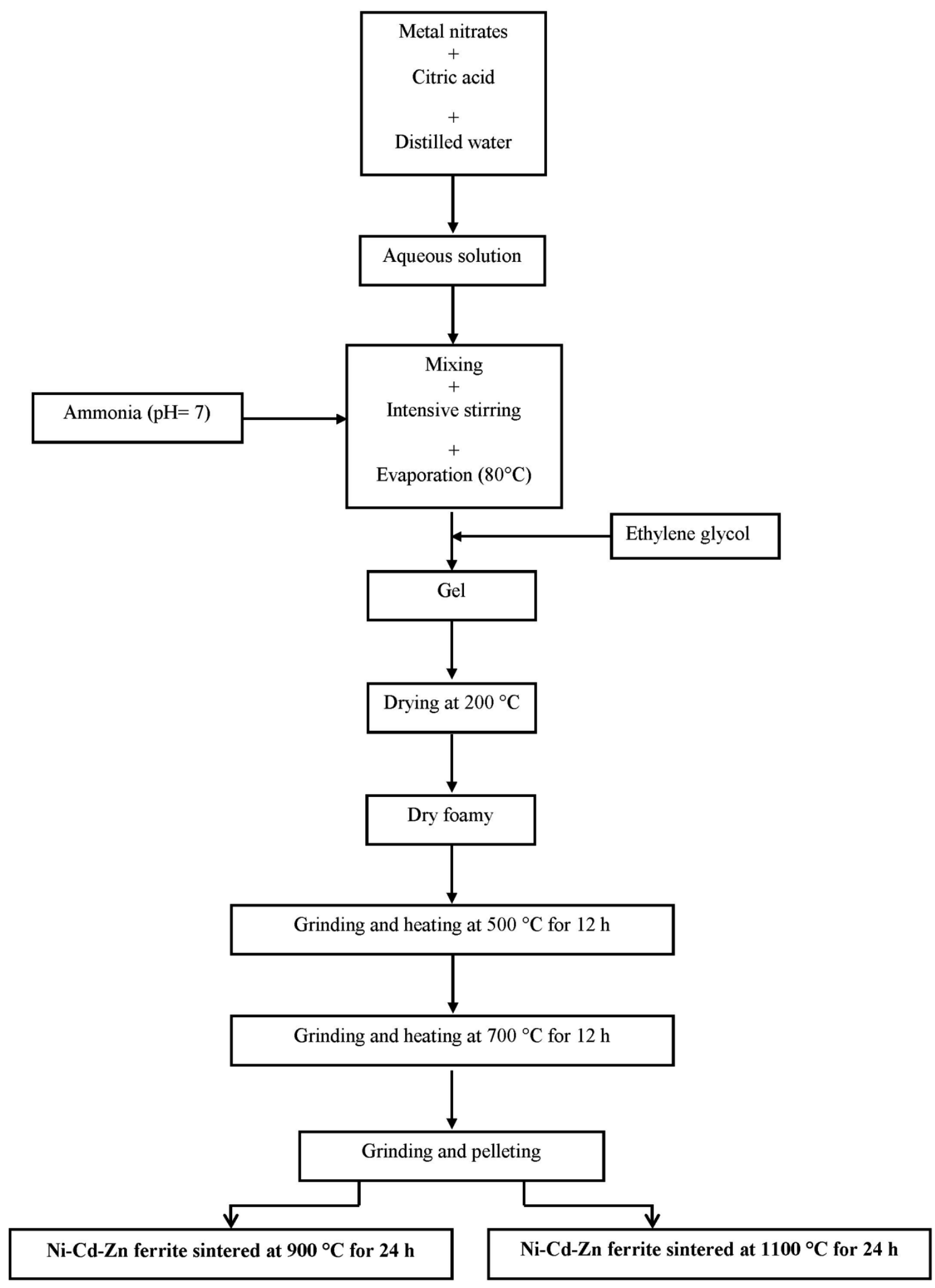

Fig. 1 

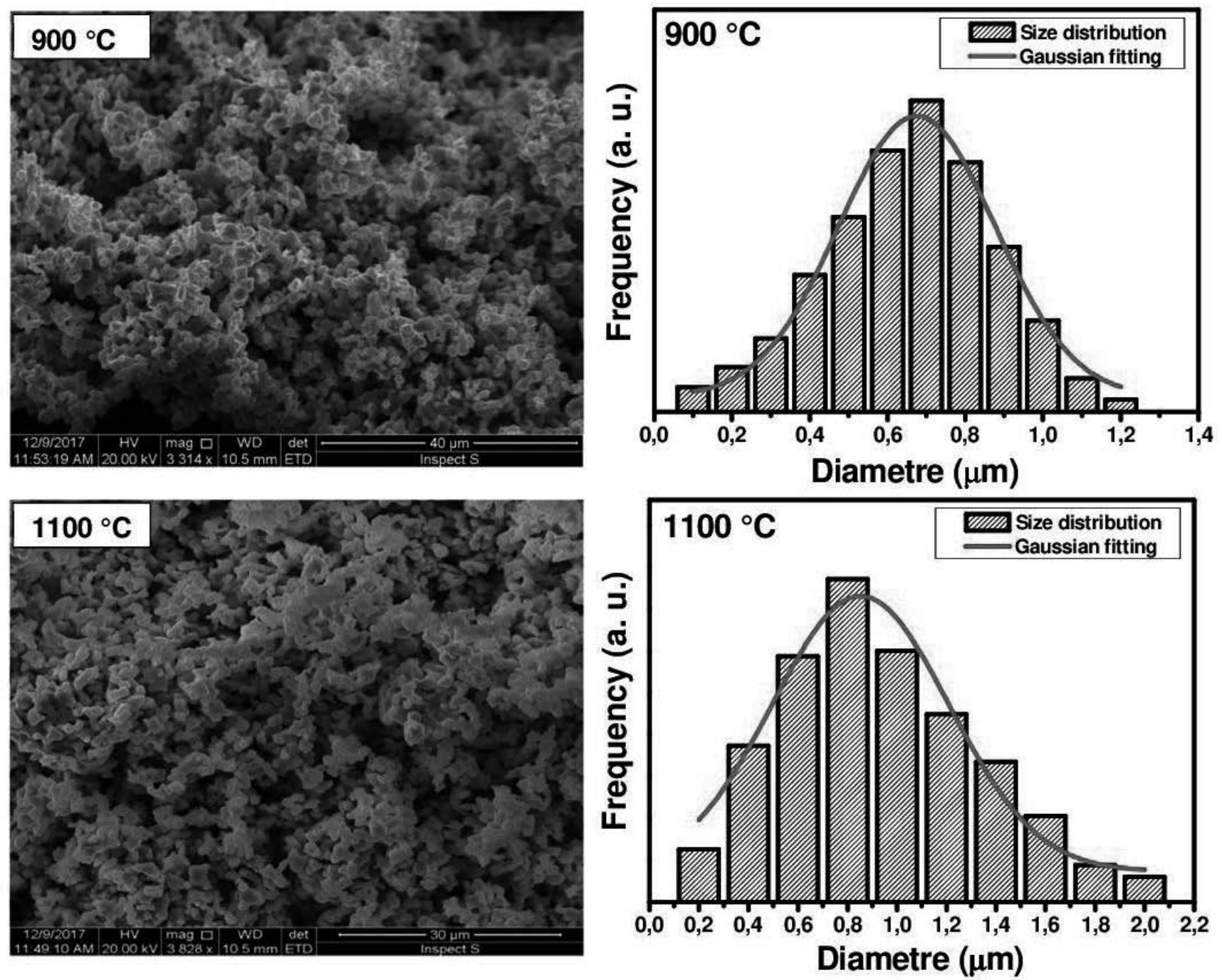

Fig. 2 


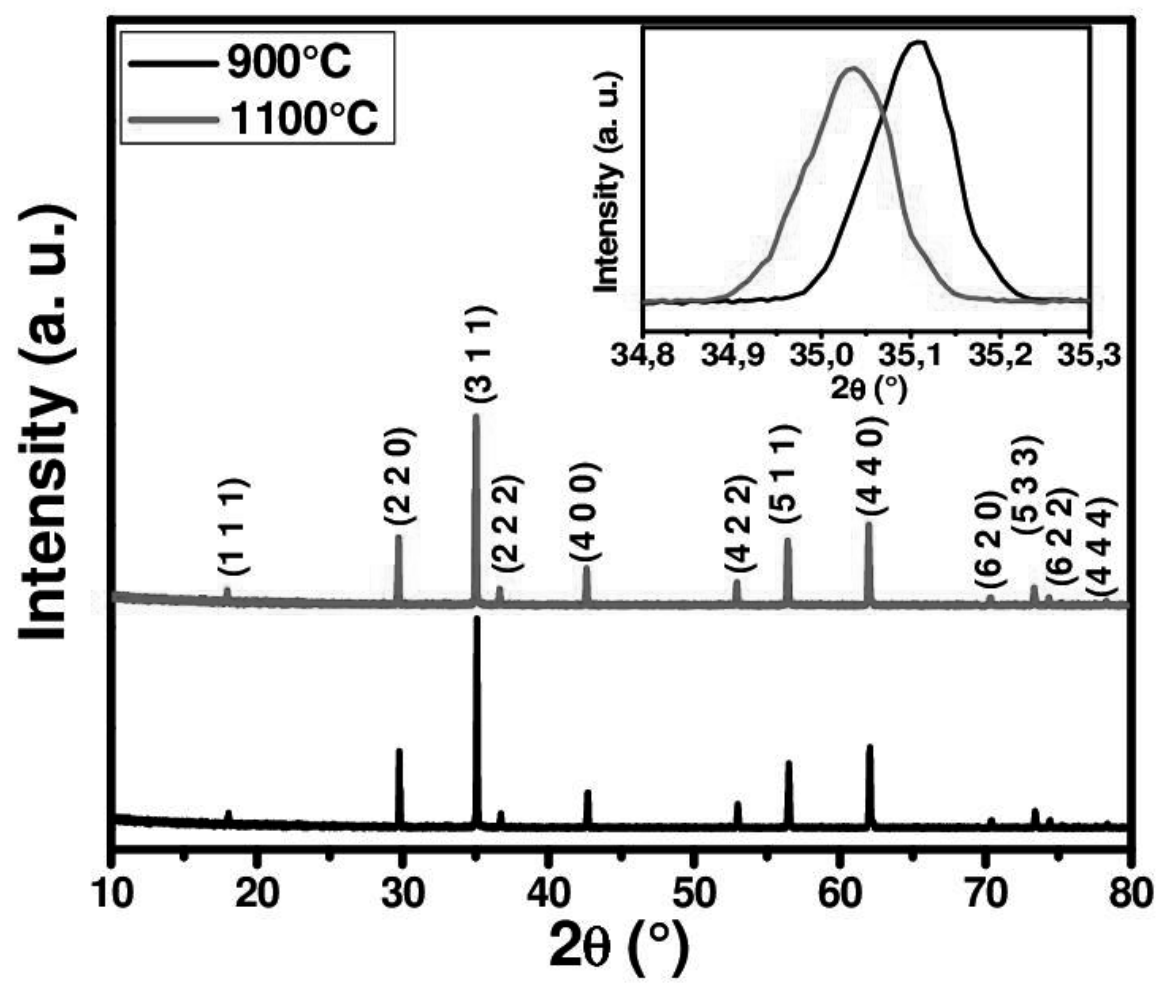

Fig. 3 

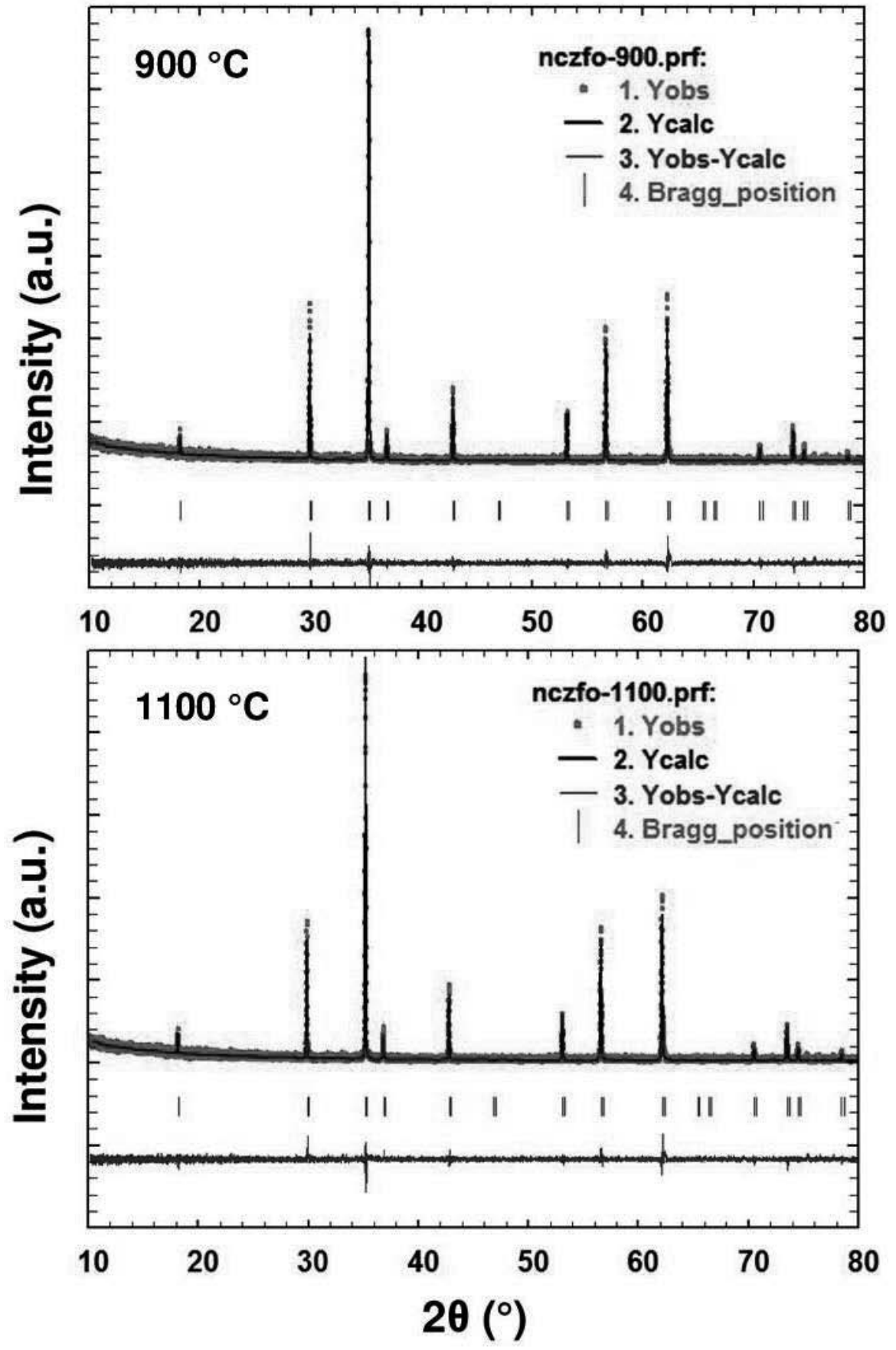

Fig. 4 


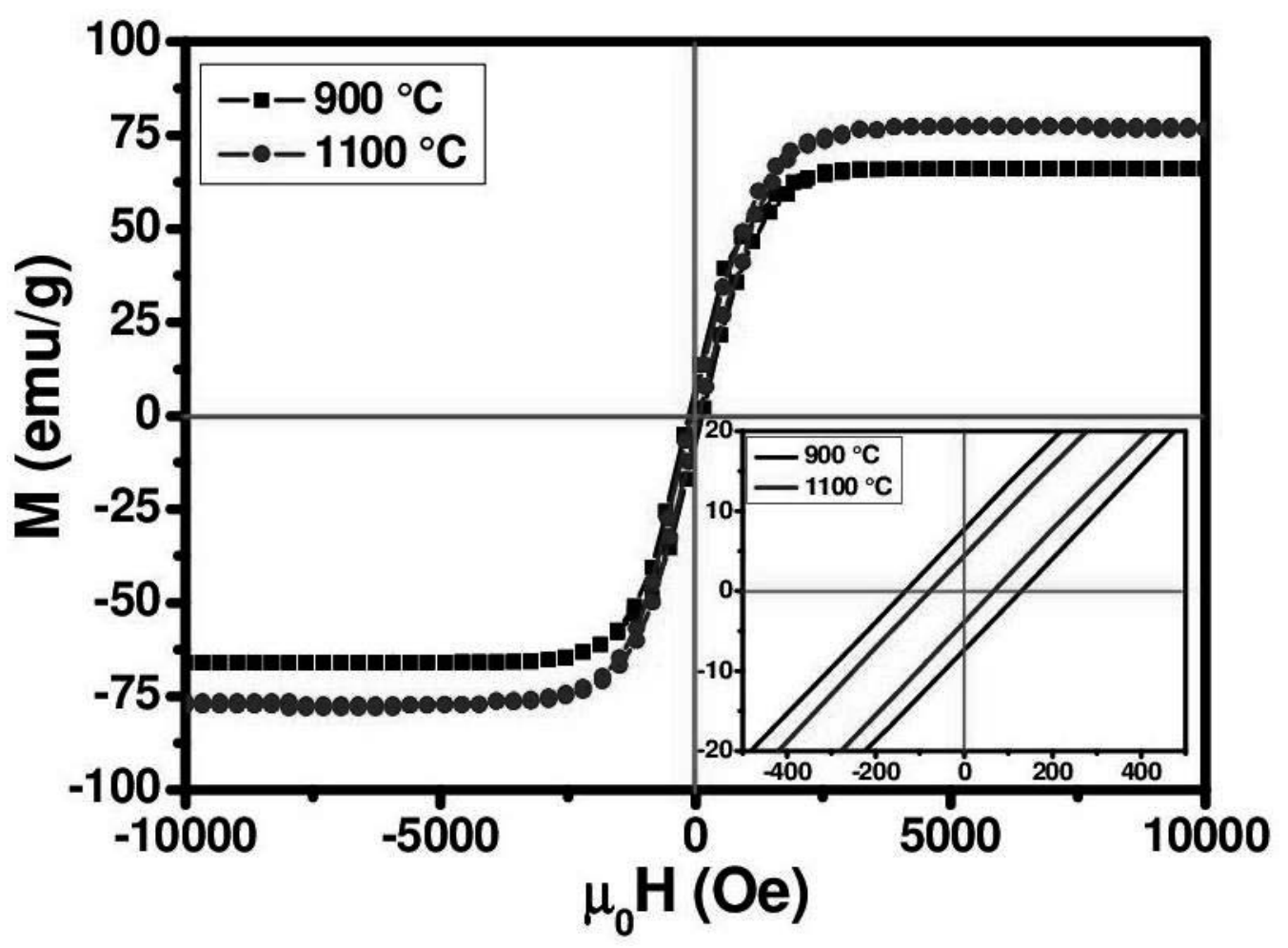

Fig. 5 


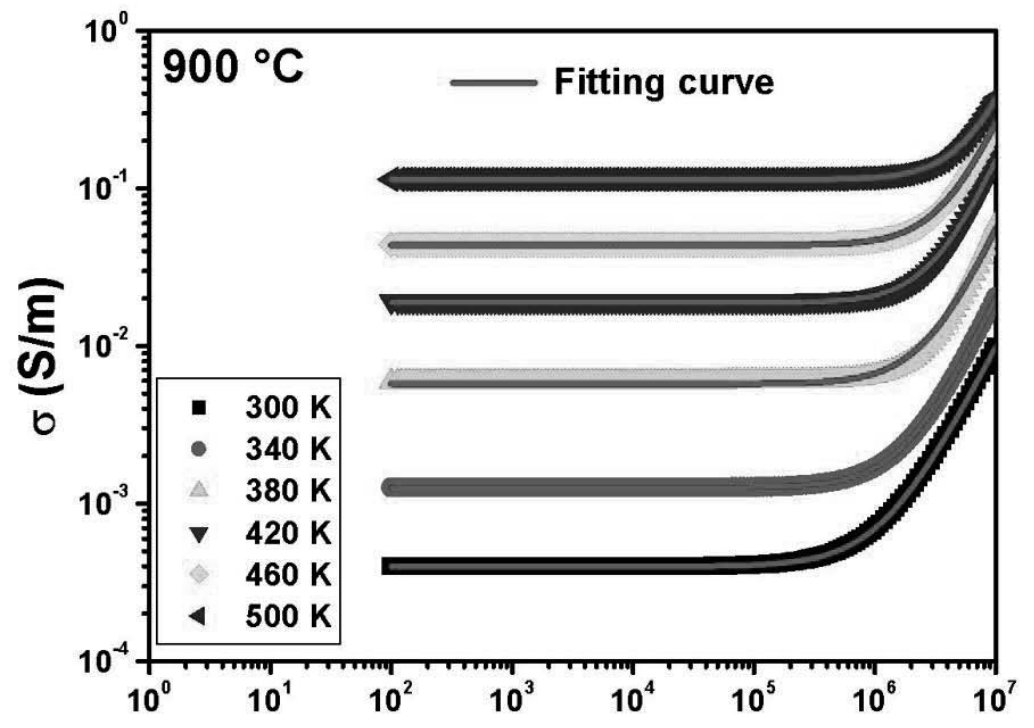

Frequency $(\mathrm{Hz})$

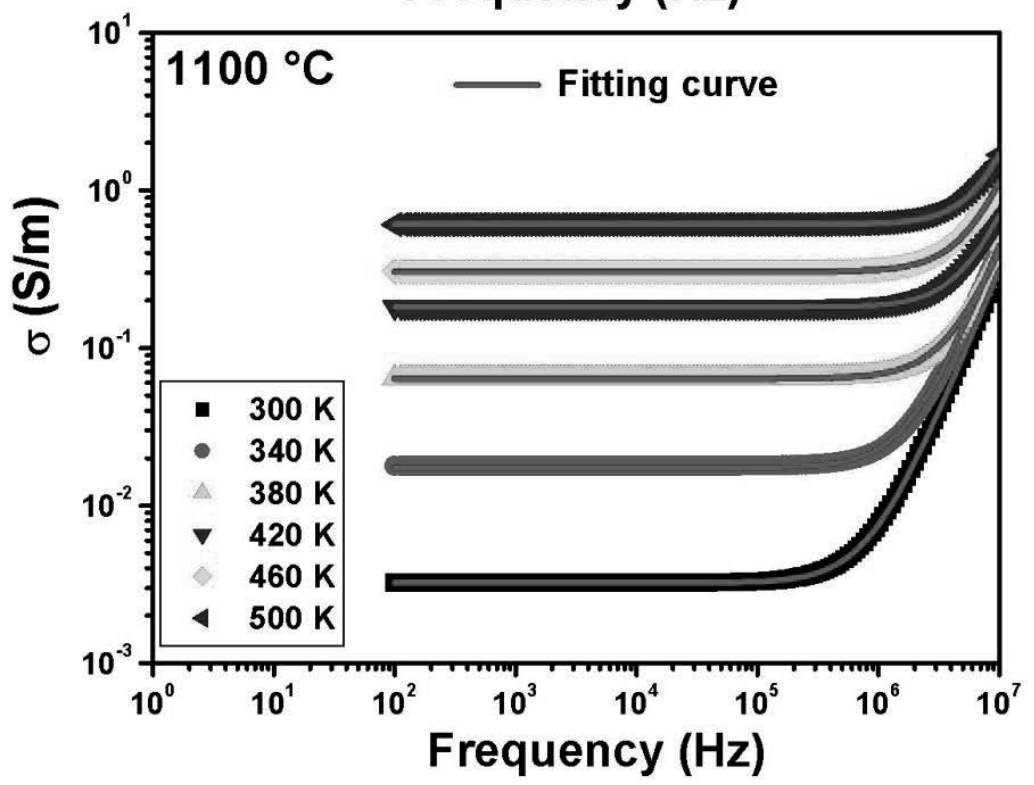

Fig. 6 


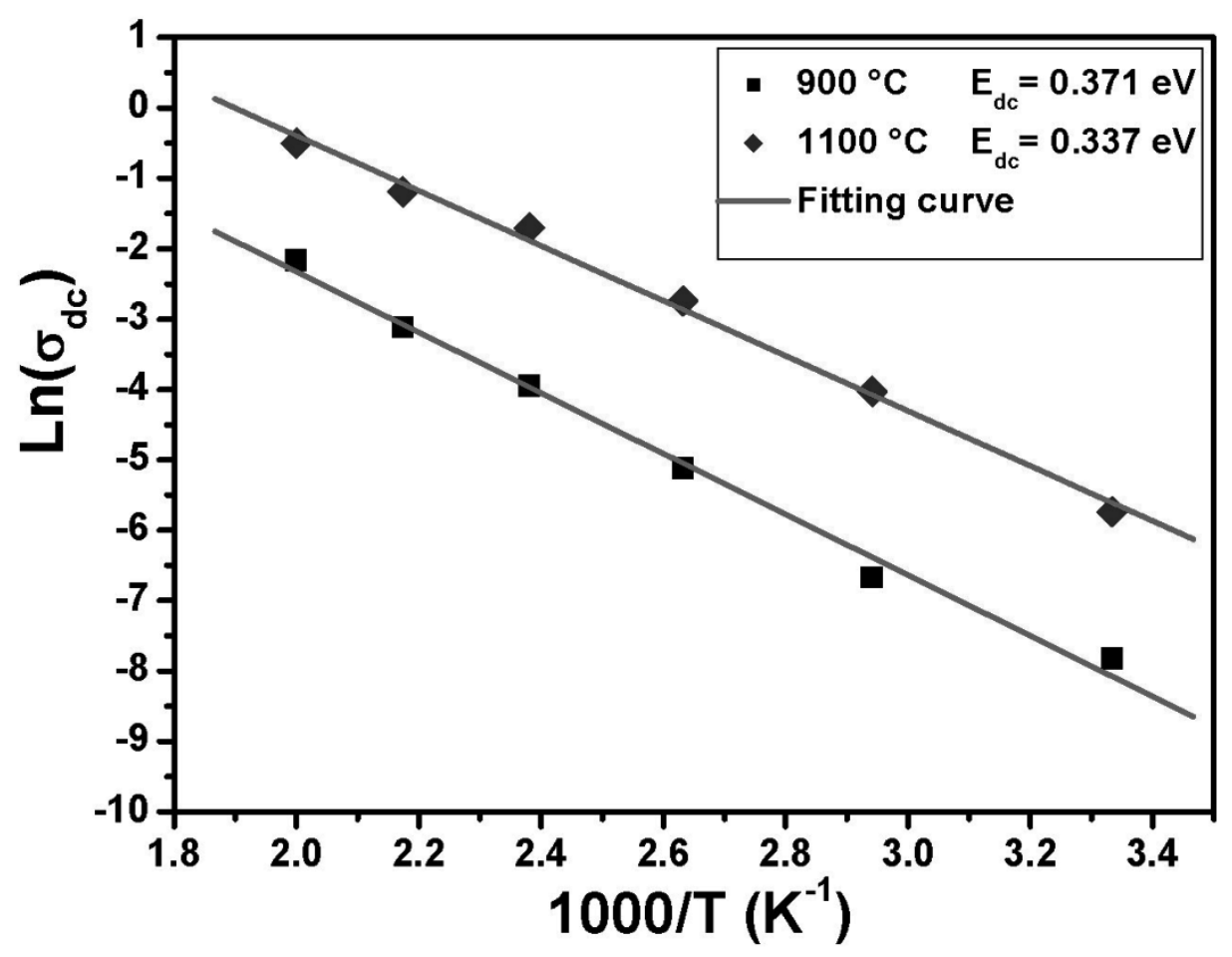

Fig. 7 

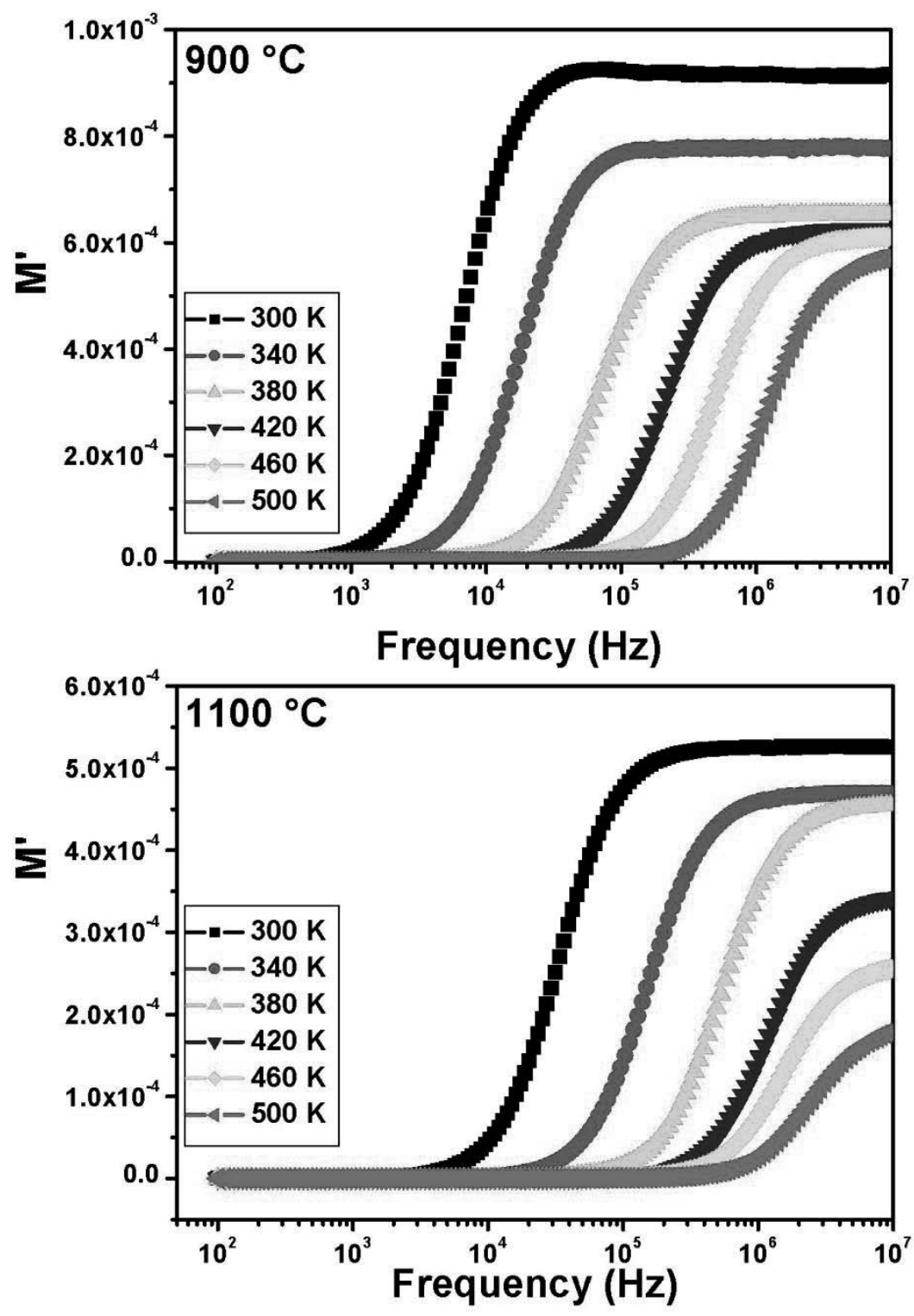

Fig. 8 

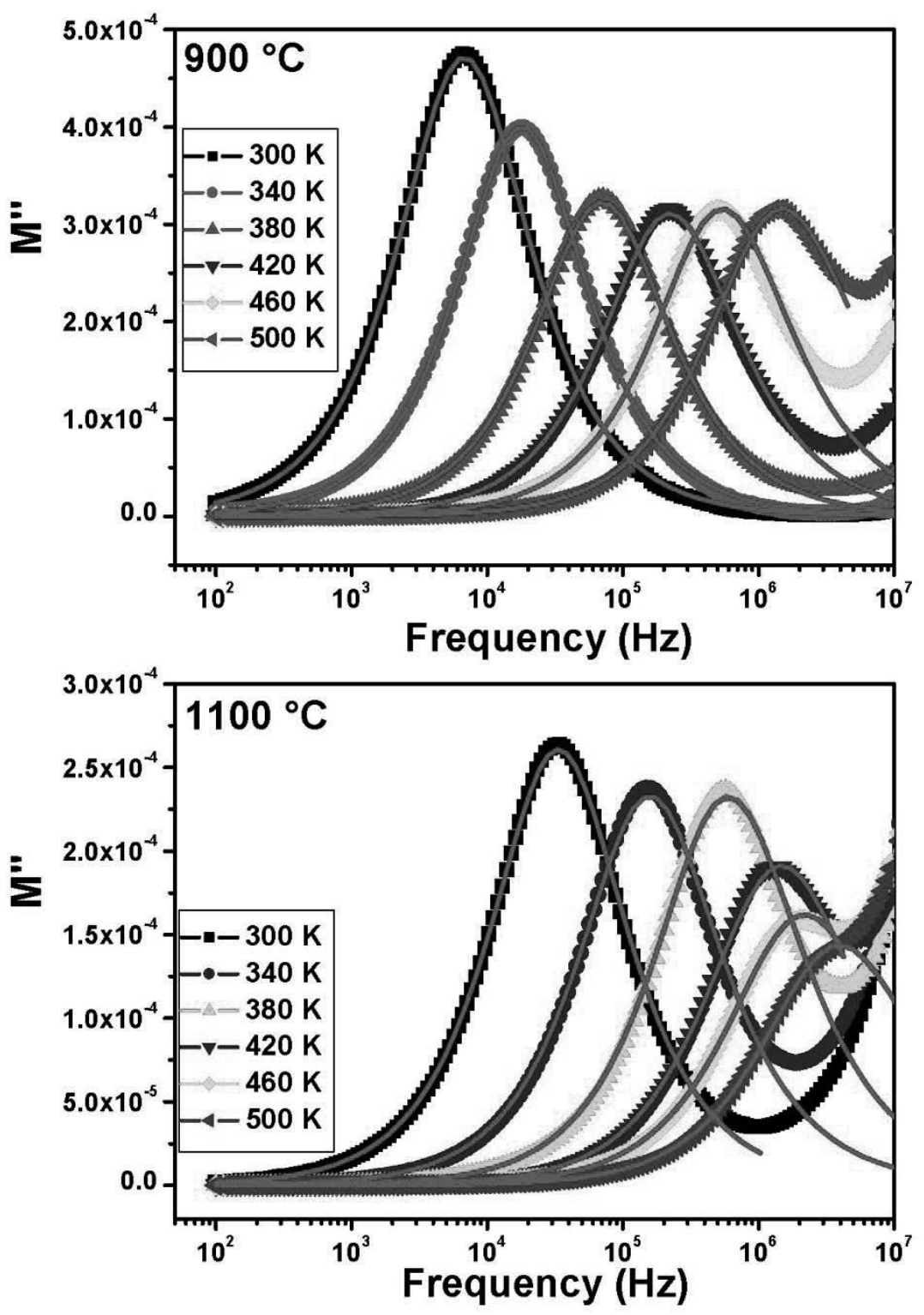

Fig. 9 


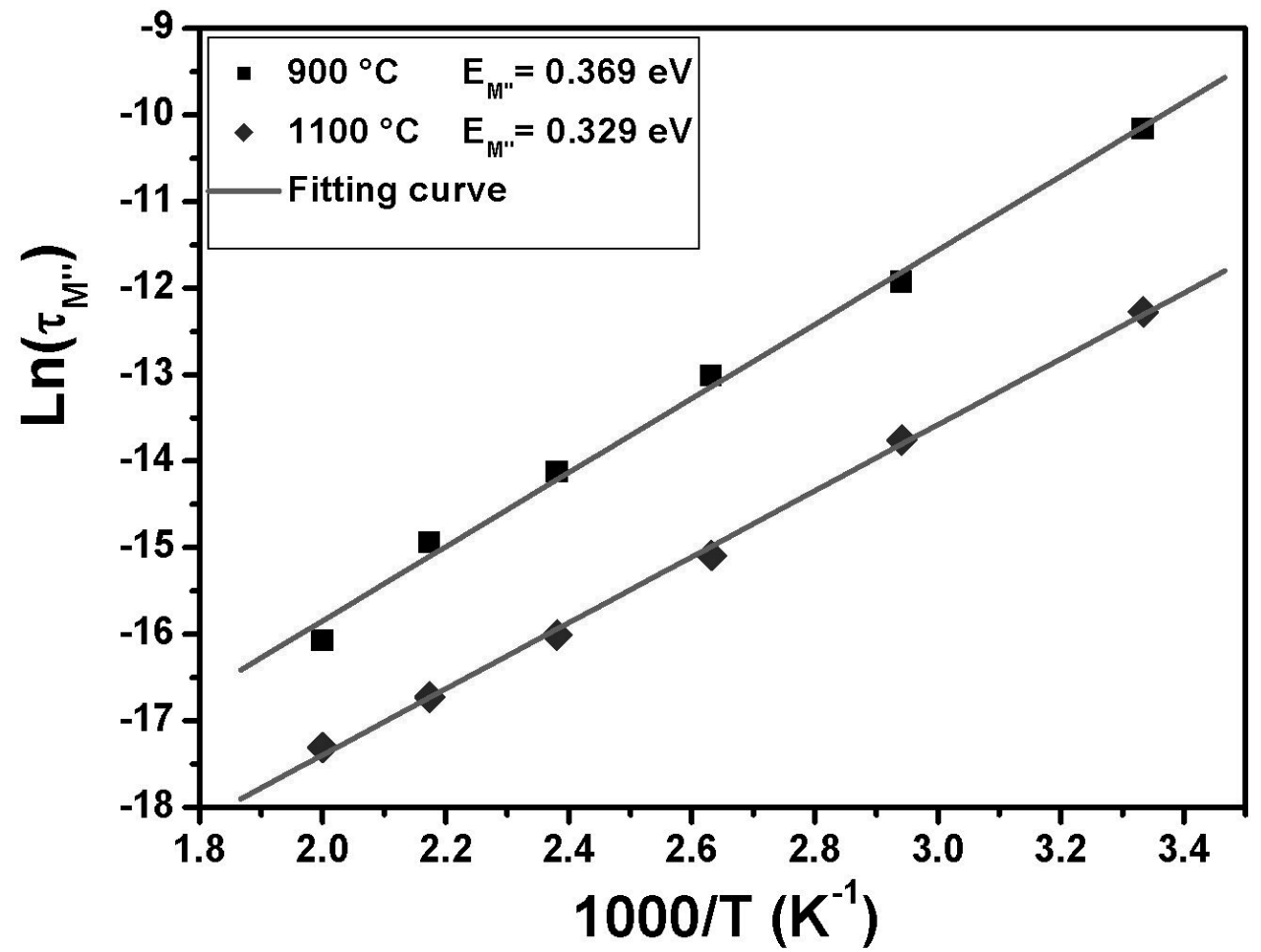

Fig. 10 

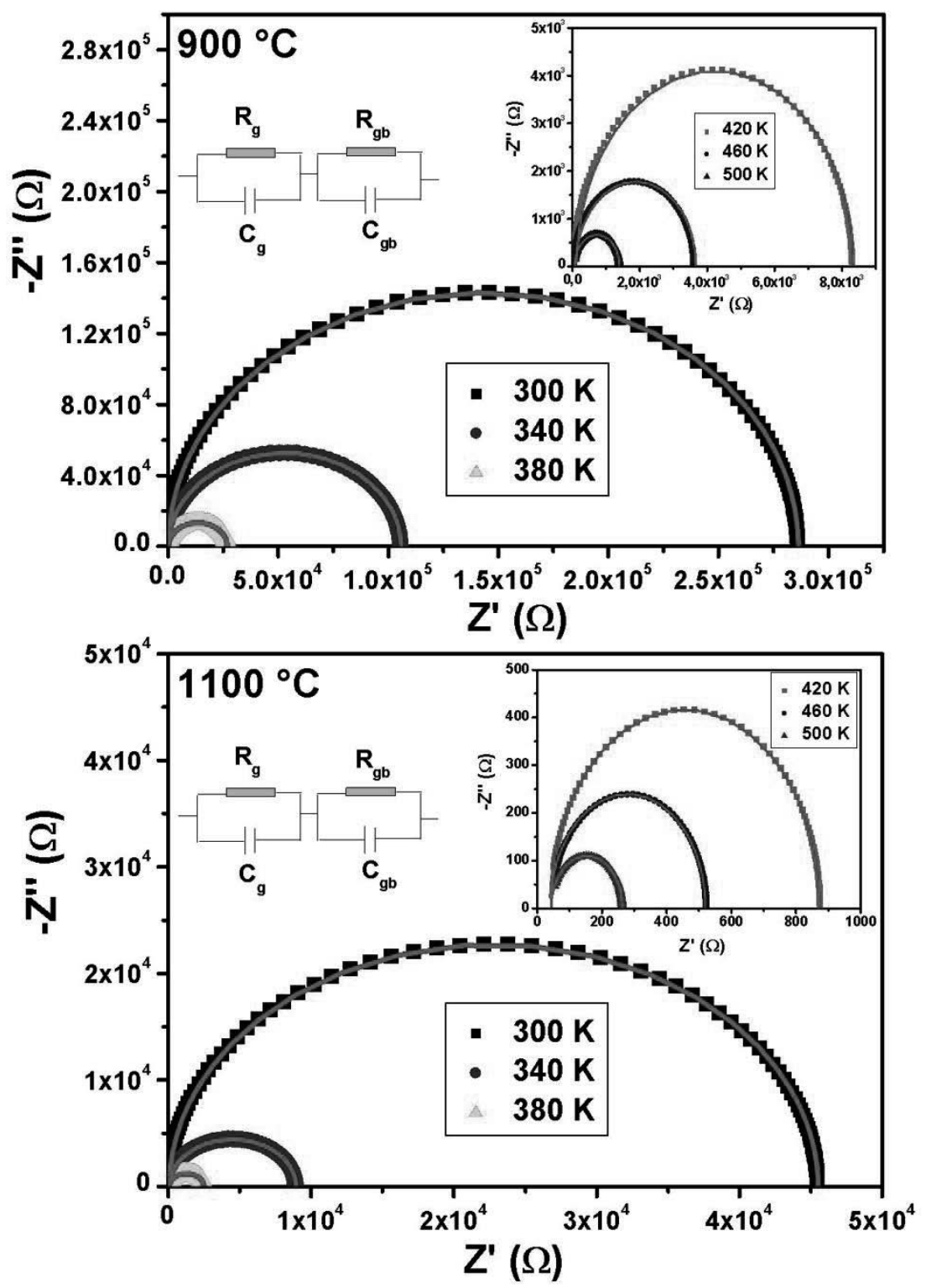

Fig. 11 